\title{
Assessing the importance of alien macro-Crustacea (Malacostraca) within macroinvertebrate assemblages in Belgian coastal harbours
}

\author{
Pieter Boets $\cdot$ Koen Lock $\cdot$ Peter L. M. Goethals
}

Received: 11 November 2010/Revised: 9 May 2011/Accepted: 11 May 2011/Published online: 26 May 2011

(C) Springer-Verlag and AWI 2011

\begin{abstract}
Harbours, which are often characterised by anthropogenic stress in combination with intensive international ship traffic, tend to be very susceptible to aquatic invasions. Since alien macrocrustaceans are known to be very successful across many European waters, a study was made on their distribution and impact in the four Belgian coastal harbours (Nieuwpoort, Ostend, Blankenberge and Zeebrugge). Biological and physical-chemical data were gathered at 43 sampling sites distributed along a salinity gradient in the four harbours. One-fourth of all crustacean species recorded were alien and represented on average $30 \%$ of the total macrocrustacean abundance and $65 \%$ of the total macrocrustacean biomass. The large share of alien crustaceans in the total macrocrustacean biomass was mainly due to several large alien crab species. Most alien species were found in the oligohaline zone, whereas the number of indigenous species slightly increased with increasing salinity. The low number of indigenous species present at low salinities was probably not only caused by salinity, but also by the lower water quality in this salinity range. Based on the site-specific biocontamination index (SBCI), which was used to assess the ecological water quality, the harbour of Nieuwpoort and Ostend scored best and were classified as good, indicating the limited abundance and the low number of alien macrocrustaceans. Sampling locations situated more inland generally had a higher SBCI and a lower ecological water quality. Zeebrugge and Blankenberge were characterised by a severe
\end{abstract}

Communicated by Luis Gimenez.

P. Boets $(\bowtie) \cdot$ K. Lock $\cdot$ P. L. M. Goethals

Laboratory of Environmental Toxicology and Aquatic Ecology,

Ghent University, J. Plateaustraat 22, 9000 Ghent, Belgium

e-mail: pieter.boets@ugent.be biocontamination. For Zeebrugge, this is probably related to the intensive transcontinental commercial ship traffic, whereas for Blankenberge, this could be due to introduction of alien species via recreational crafts or due to its geographical location in the proximity of Zeebrugge. Consistent monitoring of estuarine regions and harbours, which are seen as hotspots for introductions, could help in understanding and predicting the impact of alien species on native biota.

Keywords Alien species - Biocontamination ·

North Sea $\cdot$ Species richness

\section{Introduction}

Transcontinental commercial shipping across the oceans and aquaculture in coastal areas contributed to the spread and establishment of many alien species especially in coastal and brackish water environments (Eno et al. 1997; Reise et al. 1999; Ruiz and Hewitt 2002; Streftaris et al. 2005). Transportation and release of alien species constitutes a growing problem due to the unexpected and potentially harmful environmental as well as social and economic impacts that such invasions can cause (Streftaris et al. 2005). Moreover, human-induced climatic changes can favour the spread and settlement of alien species outside their natural biogeographical range (Kerckhof et al. 2007). At the end of the 90s, about 80 alien species established in the North Sea, which tends to be lower compared to other coastal regions in the world (Reise et al. 1999). This number is probably an underestimation since it only concerns macro-organisms. Moreover, defining the number of alien taxa is a real challenge because there are a lot of differences in the spatial and taxonomic effort 
addressed to the study of alien species. This is illustrated by Streftaris et al. (2005), who found 141 alien species in the North Sea only a few years after Reise et al. (1999) reported 80 alien taxa. Currently, 69 alien marine and coastal species have been reported from the Belgian part of the North Sea and its adjacent estuaries (VLIZ 2007). It has been found that the diversity of alien species in North Sea biota increases from offshore towards the coast and a further increase is observed from the open coast towards the estuaries (Wolff 1999). The majority of the alien species encountered are invertebrates, primarily crustaceans, molluscs, polychaetes and hydroids (Reise et al. 1999).

In this paper, we focussed on alien macrocrustaceans since these are widespread and represent, together with molluscs, the most important share of alien macroinvertebrates in several water bodies across Europe (Bernauer and Jansen 2006; Nehring 2006; Messiaen et al. 2010; Boets et al. 2011a, b). Alien macrocrustaceans are often very successful in their new habitat due to their intrinsic characteristics, such as a short generation time, rapid growth with early sexual maturity, high fecundity and their euryhaline and omnivorous character. (Bij de Vaate et al. 2002; Grabowski et al. 2007). It is known that some of these species such as Dikerogammarus villosus (Sowinsky 1894) and Chelicorophium curvispinum (Sars 1895) can cause changes in local macroinvertebrate assemblages and can have an effect on trophic links of the ecosystem (van der Velde et al. 2000; Noordhuis et al. 2009).

Most alien invertebrates colonised the North Sea via shipping, either as larvae in ballast water tanks or as adults attached to hulls (Gollasch 2006). Although there is no clear evidence that alien species have driven native species to extinction in the North Sea (Reise et al. 1999; Nehring 2006), alien species are known to have irreversibly modified certain functions of the North Sea ecosystem (Streftaris et al. 2005). As Williamson and Fitter (1996) state that most of the successful invaders are generalists, those generalists transported by ships can become abundant in harbours, because these species are often well adapted to a varying salinity and human modified environments. Besides a high physiological tolerance to survive the transport with ballast water, successful invaders are usually characterised by a high fecundity, the capacity to adapt to a new ecological niche and good means of dispersal (Streftaris et al. 2005). In addition to species characteristics, the susceptibility to invasions of the recipient ecosystem plays a crucial role in the invasion success.

Several hypotheses have been proposed to explain the high number of alien species in the meso-oligohaline brackish water zone (Wolff 1999): (1) Genuine brackish water species have a high tolerance towards fluctuations in environmental conditions and have a higher change to survive their transport; (2) Most harbours are situated in brackish water regions and therefore brackish water species stand a better chance of being transported and (3) Brackish waters are typically characterised by low natural species diversity, hence it is easier for an alien species to establish. Especially the oligohaline zone of brackish waters is characterised by a low species diversity as well as low species densities (Ysebaert et al. 1993, 2000; Seys et al. 1999). Although the low species diversity often observed in the mesohaline zone of estuaries, the few species present can reach moderate to high densities (Seys et al. 1999). It has been shown for marine ecosystems that species-rich communities appear to be better buffered against invasions (Stachowicz et al. 1999). Coastal harbours with intensive transcontinental commercial ship traffic are often characterised by brackish water conditions in the inner parts of the harbour, environmental disturbance and the presence of hard substrates. Since all of these factors favour the establishment of alien species, it is likely that many alien species have the potential to occur at these locations.

The aims of the present study were: (1) to investigate the presence of indigenous and alien macro-Crustacea in the four Belgian coastal harbours (Nieuwpoort, Oostende, Zeebrugge and Blankenberge), (2) to map the degree of biocontamination, which was expressed as the biocontamination index (Arbačiauskas et al. 2008), (3) to test the importance of several abiotic factors for the occurrence of these macro-Crustacea and (4) to assess the importance of shipping and yachting for the introduction and dispersal process of alien macro-Crustacea.

\section{Materials and methods}

The study was conducted at the four coastal harbours in Belgium: Nieuwpoort, Ostend, Blankenberge and Zeebrugge (Fig. 1) and sampling lasted from September until November 2009. Each sampling location was sampled once during this sampling campaign and consequently there was no repetition in sampling of the sampling stations. Zeebrugge and Ostend are international maritime ports, which are of high economic value to Belgium (Mathys 2009). More than 300 companies operate within the harbour area of Brugge-Zeebrugge. Zeebrugge can be characterised as a polyvalent harbour with a good geographical location, a high productivity and the possibility to enter for ships up to 55 feet depth. The harbour of Ostend is an important area for shipping, yachting and fishing. Nieuwpoort harbours mainly yachts and fishing boats, whereas Blankenberge is only visited by yachts.

Samples were taken along a salinity gradient starting in the harbour and continuing inland. In total, 43 different sampling locations including channels, docks, canals, reservoirs and small watercourses were selected of which 17 
Fig. 1 Map of the Belgian coast with indication of the different harbours and the sampled areas $(\mathbf{a}, \mathbf{b}, \mathbf{c})$, which are shown in detail in Fig. 5

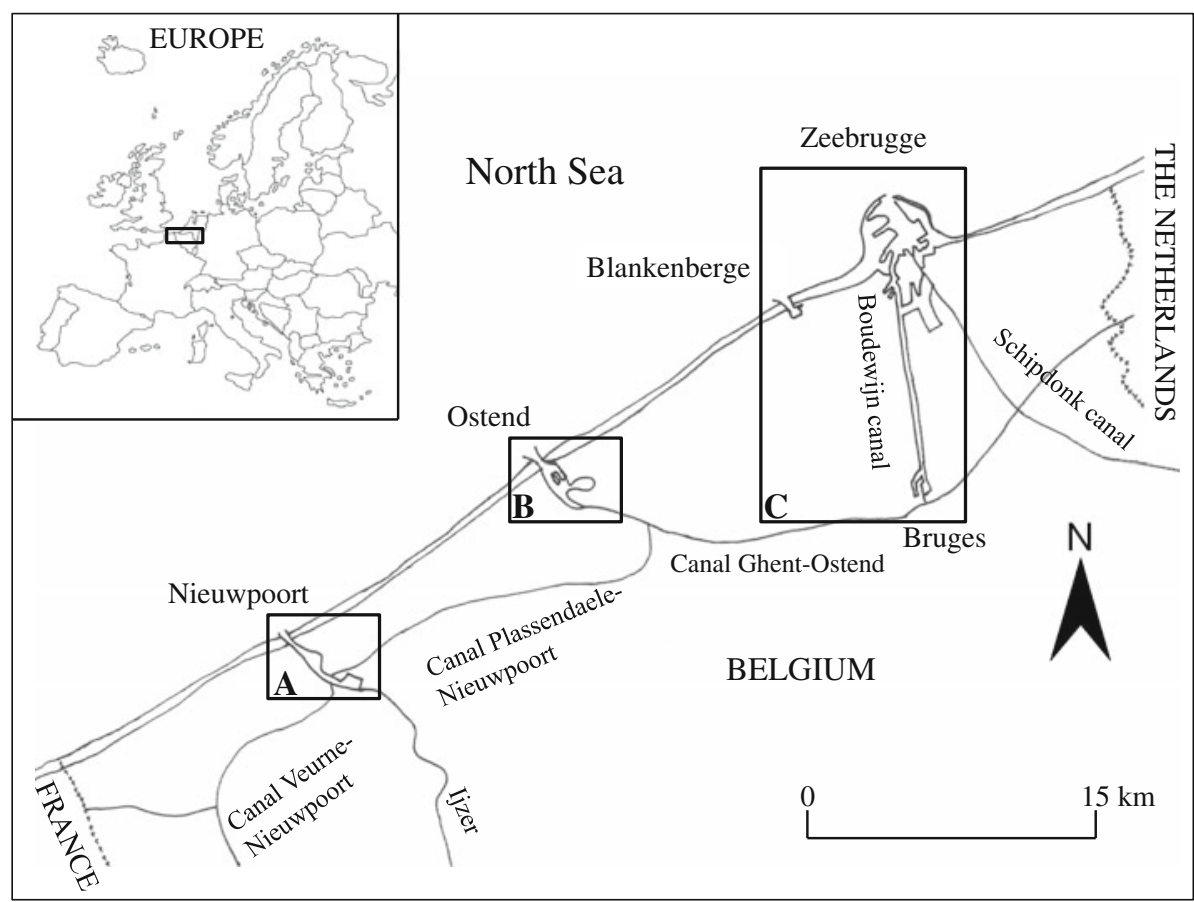

in Nieuwpoort, 11 in Ostend, three in Blankenberge and 12 in Zeebrugge-Brugge (Fig. 1). Biological samples of macroinvertebrates were collected by means of a handnet or with artificial substrates if it was not possible to perform the kick-sampling method (Gabriels et al. 2010). The handnet consists of a metal frame of approximately $0.2 \mathrm{~m}$ by $0.3 \mathrm{~m}$ to which a conical net is attached with a mesh size of $300 \mu \mathrm{m}$. With the handnet, a stretch of approximately 10-20 m was sampled during approximately $3 \mathrm{~min}$. Sampling effort was proportionally distributed over all accessible aquatic habitats. In combination with the handnet sampling, animals were manually picked from stones along the same stretch (Gabriels et al. 2010). Artificial substrates consisted of polypropylene bags $( \pm 51)$, containing bricks of different sizes. At each sampling site, three replicate bags were placed in the water, anchored with a rope to a fixed point located on the bank. The substrates were left in the water for a period of 3-4 weeks after which they were retrieved. In this way, species could colonise the substrates. Handnet sampling in combination with manual picking and artificial substrates were two methods used for quantitative analysis. Both sampling methods were used to sample the macrobenthos communities living in or near the surface of the substrate.

Besides the abovementioned sampling techniques, a trawl net with a circular diameter of $100 \mathrm{~cm}$, a length of $3 \mathrm{~m}$ and a mesh size of $200 \mu \mathrm{m}$ was used to sample the hyperbenthos. This sampling method was used for qualitative analysis only and the samples were used to assess the species present in the water column between 0.2 and $1.2 \mathrm{~m}$ above the bottom. This sampling technique was used to catch mobile species such as Mysida, since these are often missed when using a handnet or artificial substrates. The trawl net was with a long rope attached to a zodiac and left into the water to the appropriate depth for sampling. Samples were taken by sailing within a radius of $100 \mathrm{~m}$ from a predetermined fixed sampling location (GPS determined) within the harbour for $10 \mathrm{~min}$ at an average ship speed $(4 \mathrm{~km} / \mathrm{h}$ relative to the bottom). All samples were taken during day time when hyperbenthic organisms are known to be concentrated near the bottom. The samples gathered by trawl net were not included in the analysis of abundance, number of species and biomass data, because the sampling method could not be compared to the other sampling techniques used since the quantities sampled differed between the trawl net on the one hand and the handnet and artificial substrates on the other hand.

All macroinvertebrates were preserved in $90 \%$ alcohol and afterwards identified in the laboratory to species level. All individuals of each species were measured based on the standard length (distance from base of the rostral tip to the end of the last abdominal segment for most species, but carapace width for crabs) and their biomass was derived from length-ash-free dry weight regressions (Mees 1994).

One water sample for chemical analysis was taken at each sampling location. Dissolved oxygen (wtw oxi 330), conductivity (wtw cond 315i) and $\mathrm{pH}(\mathrm{HI} 9210 \mathrm{~N}$ ) were measured in the field by means of a hand electrode. Salinity was measured with a refractometer (DIGIT ATC 100). Ammonium, nitrite, nitrate and total phosphorous were determined in the laboratory using test kits (Merck 
Spectroquant) specifically designed for the analysis of water with a high chloride content.

Since alien species constitute a significant biological pressure, the assessment of such a pressure should be integrated within the context of the ecological status assessment of water bodies required by the European Water Framework Directive (Cardoso and Free 2008). In order to provide an integrated ecological assessment of alien species, a biocontamination index was established (Arbačiauskas et al. 2008). This "biocontamination" could be defined as the presence of alien species regardless of their abilities to cause negative ecological and/or socioeconomic impacts (Panov et al. 2009). The biocontamination of the sampling sites was assessed using a site-specific biocontamination index (SBCI) derived from two metrics: abundance contamination index (ACI) and richness contamination index (RCI) at ordinal rank (Arbačiauskas et al. 2008). These indices were calculated as: ACI $=N_{\mathrm{a}} / N_{\mathrm{t}}$, where $N_{\mathrm{a}}$ and $N_{\mathrm{t}}$ are the total number of alien individuals and the total number of individuals in a sample, respectively and RCI $=T_{\mathrm{a}} / T_{\mathrm{t}}$, where $T_{\mathrm{a}}$ is the total number of alien species and $T_{\mathrm{t}}$ is the total number of species per sample. The SBCI may be derived from values of ACI and RCI (Arbačiauskas et al. 2008). Five classes of biocontamination ranging from zero (no contamination) to four (severe contamination) could be defined. The classes of SBCI correspond to the five ecological quality classes as defined by the European Water Framework Directive (2000/60/EC; European Community 2000) and allow status ranking of water bodies from high to bad quality. For the calculation of the SBCI, all taxa (macro-Crustacea and other macroinvertebrate taxa) were included. The relationship between shipping, the SBCI and the number and abundance of alien species was analysed using Spearman's Rank Correlation Coefficient. The relative abundance, number of species and biomass were calculated as the total value of alien species divided by the total value of all species. A non-parametric Kruskal-Wallis ANOVA was used to check for differences in number of species, abundance and biomass between harbours. Post-hoc multiple comparisons were used to assess differences between specific harbours (Conover 1980). All statistical analyses were performed using Statistica 7.0 (StatSoft and Inc 2004).

Data on shipping were obtained from several information sources depending on the type of shipping. Information on transcontinental shipping (ship movements as well as the origin of ships), which includes container traffic, transportation of goods, roll-on roll-off and transportation of passengers, was obtained from the annual reports made by the Flemish harbours (Merckx and Neyts 2008). Information on recreational crafts originated from the logbooks of different marinas. For Ostend and Nieuwpoort, the number of yachts entering the marina was documented in logbooks, whereas for Blankenberge and Zeebrugge, no information on the number of recreational craft movements was available. Therefore, estimations were made about the number of yachts entering these marinas. The number of anchorages in each of the marinas was counted based on aerial photographs. Based on that number and information available of the yacht movements of Ostend and Nieuwpoort, an extrapolation for Zeebrugge and Blankenberge was made. Finally, information on the number of fishing vessels entering Zeebrugge, Ostend and Nieuwpoort on an annual base was retrieved from the Department of Ocean Fisheries (www.vlaanderen.be/landbouw).

\section{Results}

Physical-chemical data analysis

Maximum concentrations of ammonium, nitrite and total phosphorous were found in Nieuwpoort (Table 1). In Blankenberge, Nieuwpoort and Ostend, most samples were evenly distributed over a salinity gradient ranging from almost fresh (2 PSU) to saline (35 PSU) water. In Zeebrugge, all samples were taken in the range of 28-35 PSU, although they were located up to $15 \mathrm{~km}$ inland. The water was alkaline with a pH ranging between 7.22 and 9.12. Dissolved oxygen was rather low for Ostend with a minimum of $1.09 \mathrm{mg} \mathrm{l}^{-1}$ and a maximum of $5.62 \mathrm{mg}^{-1}$. Maximum values for dissolved oxygen were around $10 \mathrm{mg}^{-1}$ for Nieuwpoort, Blankenberge and Zeebrugge (Table 1).

\section{Shipping}

Only two out of four harbours received transcontinental commercial ship traffic: Zeebrugge and Ostend with 9405 and 4868 ships entrances reported during the year 2008, respectively. For Zeebrugge, 55\% of the ships originated from Europe, $30 \%$ from Asia and 2\% from North America, whereas for Ostend, almost all ships originated from within Europe (99.5\%). Information on the traffic of recreational crafts was directly available for Ostend and Nieuwpoort with 1,255 and 1,391 yachts entering the marina in 2009, respectively. About $25 \%$ were yachts coming from neighbouring marinas in Belgium, the other $75 \%$ of the yachts entering the marinas originated from other harbours situated in Europe. Since no detailed data on traffic of yachts were available for Blankenberge and Zeebrugge, estimations were made on the number of yachts entering these marinas, which resulted in 570 yachts for Zeebrugge and 1,140 yachts for Blankenberge. Based on data of 2009, it was found that most fishing vessels entered in Ostend 
Table 1 Measured ranges for dissolved oxygen (DO), salinity, conductivity (EC), ammonium $\left(\mathrm{NH}_{4}\right)$, nitrate $\left(\mathrm{NO}_{3}\right)$, nitrite $\left(\mathrm{NO}_{2}\right)$, total phosphorous ( $\mathrm{P}$ total) and $\mathrm{pH}$ in the Belgian coastal harbours

\begin{tabular}{|c|c|c|c|c|c|c|c|c|}
\hline Harbour & $\begin{array}{l}\text { DO } \\
\left(\mathrm{mg} \mathrm{l}^{-1}\right)\end{array}$ & $\begin{array}{l}\text { Salinity } \\
\text { (PSU) }\end{array}$ & $\begin{array}{l}\mathrm{EC} \\
\left(\mathrm{mS} \mathrm{cm} \mathrm{cm}^{-1}\right)\end{array}$ & $\begin{array}{l}\mathrm{NH}_{4} \\
\left(\mathrm{mg} \mathrm{N}^{-1}\right)\end{array}$ & $\begin{array}{l}\mathrm{NO}_{3} \\
\left(\mathrm{mg} \mathrm{N}^{-1}\right)\end{array}$ & $\begin{array}{l}\mathrm{NO}_{2} \\
\left(\mathrm{mg} \mathrm{N}^{-1}\right)\end{array}$ & $\begin{array}{l}\mathrm{P} \text { total } \\
\left(\mathrm{mg} \mathrm{P}^{-1}\right)\end{array}$ & $\mathrm{pH}$ \\
\hline Blankenberge & $7.00-10.30$ & $7-35$ & $6.43-49.60$ & $0.05-0.16$ & $0.60-1.49$ & $0.01-0.05$ & $0.14-1.05$ & $7.85-9.12$ \\
\hline Nieuwpoort & $2.98-9.91$ & $3-35$ & $1.78-51.80$ & $0.10-1.02$ & $0.12-1.61$ & $0.01-0.70$ & $0.20-4.86$ & $7.82-8.44$ \\
\hline Ostend & $1.09-5.62$ & $2-35$ & $1.92-43.90$ & $0.05-0.59$ & $0.98-5.64$ & $0.01-0.10$ & $0.20-1.33$ & $7.64-8.72$ \\
\hline Zeebrugge & $4.50-9.80$ & $28-35$ & $36.30-47.70$ & $0.05-0.21$ & $1.03-1.91$ & $0.01-0.17$ & $0.20-1.40$ & $7.22-7.78$ \\
\hline
\end{tabular}

$(n=882)$, followed by Nieuwpoort $(n=612)$ and Zeebrugge $(n=240)$. There were no fishing vessels entering the harbour of Blankenberge. A significant correlation was found between the total number of ship entrances and the number of alien species recorded per sample $(R=0.405$; $P=0.04$ ), which increased with increasing ship traffic.

Biological data analysis

A total of 42 macro-Crustacea were found, 11 of which were alien to Belgium (Table 2). Hemigrapsus takanoi Asakura and Watanabe 2005, Gammarus tigrinus (Sexton 1939) and Caprella mutica Schurin 1935 were the most frequently encountered alien macro-Crustacea. The other alien macrocrustaceans were recorded in less than $10 \%$ of the samples. Almost $50 \%$ of the alien species originated from North America, 27\% from East Asia, 18\% from the Ponto-Caspian region and $9 \%$ from New Zealand. The most common indigenous species were Microdeutopus gryllotalpa Costa 1835, Melita palmata (Montagu 1804) and Carcinus maenas (Linnaeus 1758), which were all recorded in almost half of the samples.

In general, about $25 \%$ of all macrocrustacean species were alien and they accounted for $30 \%$ of the total macrocrustacean abundance in the Belgian coastal harbours (Fig. 2). These alien species accounted for more than $65 \%$ of the total relative biomass of macrocrustaceans, which is primarily due to the alien crab $H$. takanoi and the amphipod $G$. tigrinus. When analysing the presence of alien macro-Crustacea per harbour, Ostend had the highest total relative abundance of alien species, whereas Zeebrugge the lowest (Fig. 2). However, with Kruskal-Wallis ANOVA, no significant difference in abundance of alien macroCrustacea was detected between the harbours $\left(\chi^{2}=1.69\right.$, $d f=3, P=0.64)$. The total relative number of alien species was more or less similar among the large harbours, with the highest number of alien species found in Zeebrugge (Fig. 2). A significant difference between Nieuwpoort, which contained the lowest percentage of alien macrocrustacean species and Zeebrugge, which contained the highest percentage $\left(H_{3}=8.17, n=43, P=0.04\right)$ was indicted by post hoc multiple comparisons. The lowest total number of alien macrocrustaceans was found in Blankenberge, where they represented more than $90 \%$ of the total relative biomass (Fig. 2). This was mainly due to the crab species $H$. takanoi, which was found in high numbers (60 individuals per sample). The harbour of Nieuwpoort and adjacent water bodies seemed to be least dominated by alien macro-Crustacea when considering total relative abundance, total relative number of species and total relative biomass.

An analysis of the relationship between the chemical water quality parameters and the abundance of macroCrustacea revealed some differences in their preferences for the chemical water composition. Based on salinity, a clear distinction could be made between the typical freshand brackish water species and the more marine species (Fig. 3). Based on the concentrations of ammonium, nitrite, nitrate and total phosphorous, it could be concluded that $G$. tigrinus, Dikerogammarus villosus and Asellus aquaticus (Linnaeus 1758) were present in the most polluted waters, which were mostly situated in the oligohaline zone (Fig. 3). There was no clear difference in chemical water quality preference between alien and indigenous species based on the different parameters measured.

\section{Number of species and biocontamination}

The salinity range was divided based on the Venice system (1959), which consist of an oligohaline (0.5-5 PSU), mesohaline (5-18 PSU), polyhaline (18-30 PSU), euhaline (30-40 PSU) and hyperhaline zone ( $>40$ PSU). The average number of indigenous species found per sample was highest at salinities above 30 PSU (Fig. 4). The average number of alien species found per sample was highest at the oligo- (0.5-5 PSU) and mesohaline (5-18 PSU) zone. The number of alien macroinvertebrates seemed to reach a maximum at salinities below 5 PSU, whereas the number of indigenous species slightly increased with increasing salinity (Fig. 4). The lower number of indigenous species observed at lower salinities was probably related to the low water quality in many of the canals and rivers situated in the oligohaline zone. 


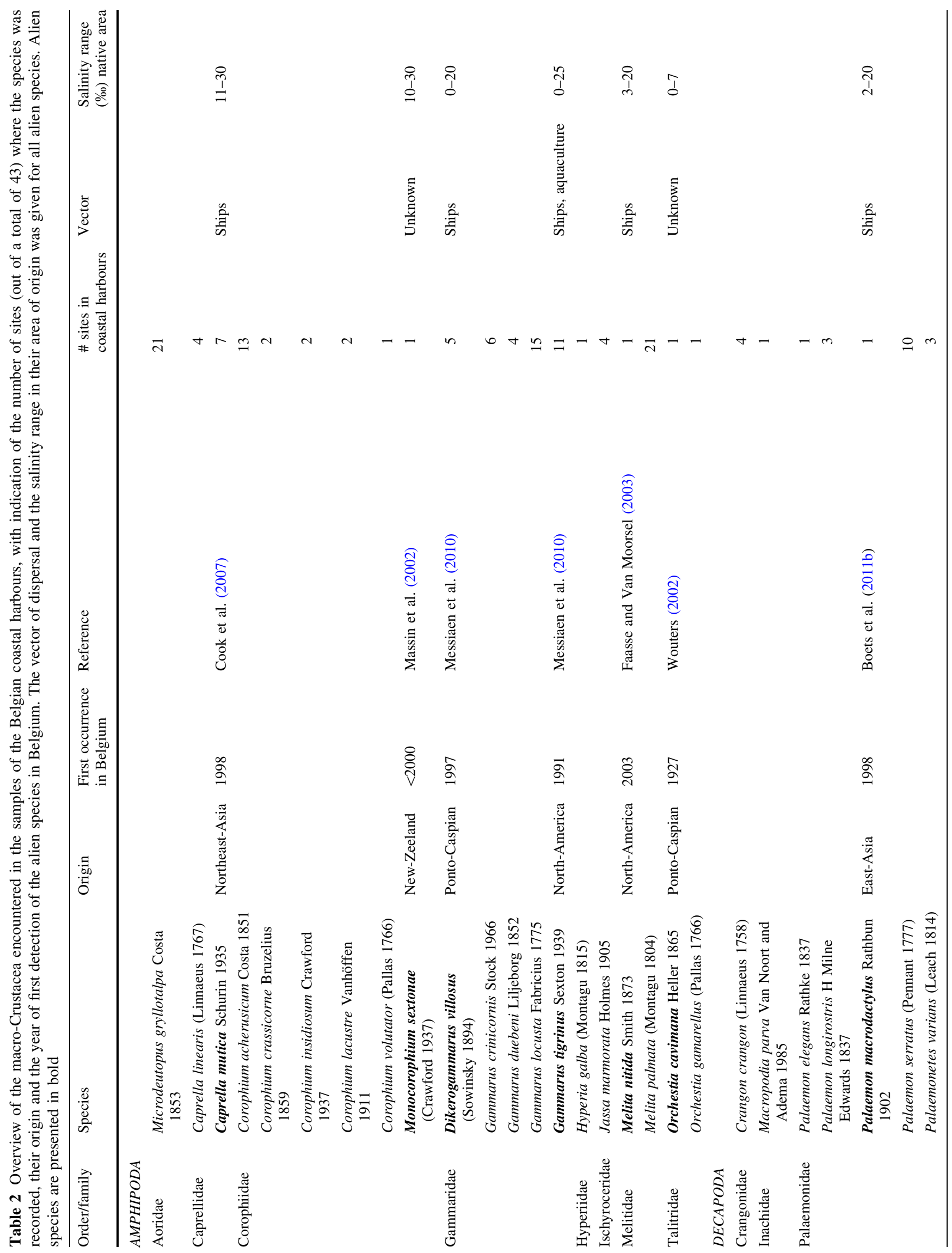




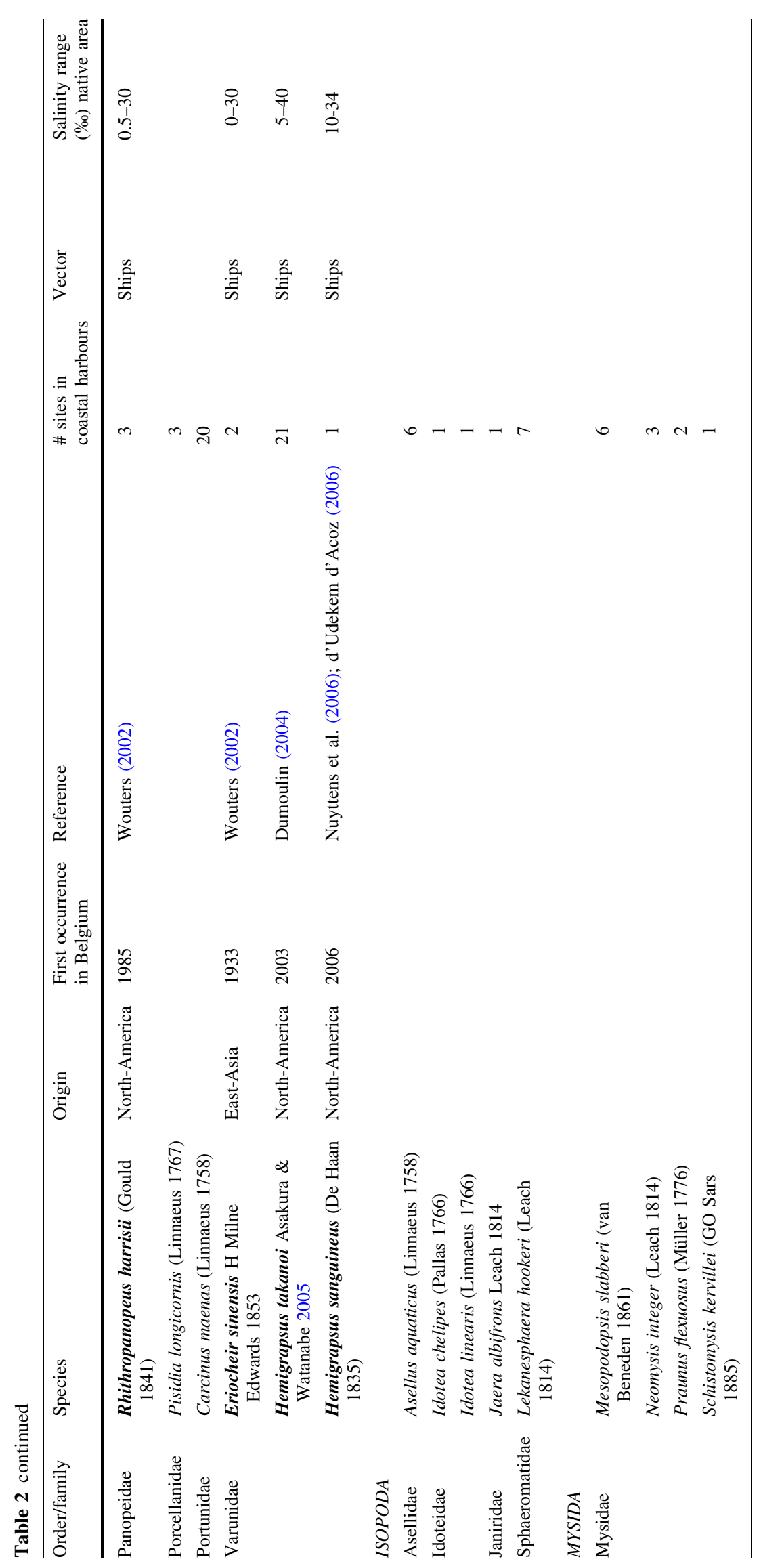




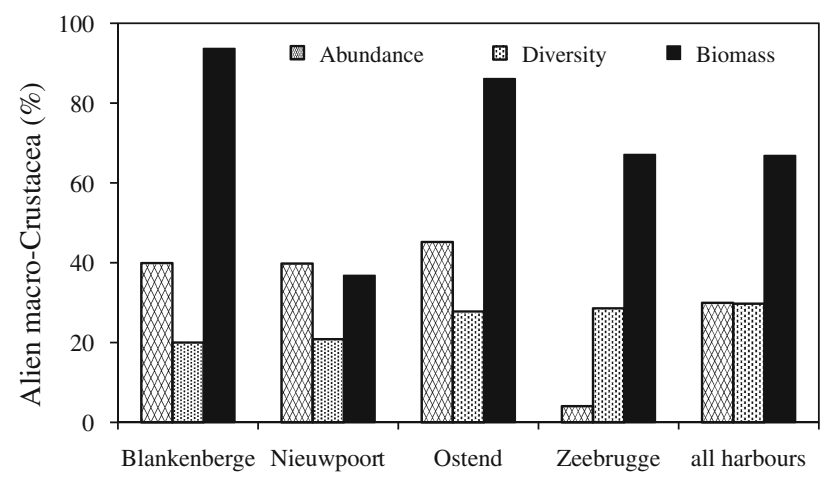

Fig. 2 The relative percentage of macro-Crustacea being alien in terms of total abundance, total number of species and total biomass for Blankenberge, Nieuwpoort, Ostend, Zeebrugge and all harbours

The presence of alien species and the biocontamination at the different sampling points has been mapped (Fig. 5). Most sampling locations situated within the harbour of Nieuwpoort and Ostend had a low biocontamination index and consequently a good to moderate status (Fig. 5a, b). One sampling point situated in the marina of Nieuwpoort had a SBCI of 4, which was due to high densities of Crassostrea gigas (Thunberg 1793) and H. takanoi. It was observed for Nieuwpoort and Ostend that sampling locations situated more inland were categorised in class 3 or 4 and thus were characterised by a high number or high densities of alien species. In Zeebrugge, most sampling locations scored bad regarding biocontamination, while bio-uncontaminated sites were lacking (Fig. 5c). Some sampling locations situated within the harbour docks of Zeebrugge and the harbour of Blankenberge were characterised by high abundances of $H$. takanoi and C. mutica and were consequently categorised in class 3 or 4 . The SBCI was positively correlated with the number of alien species $(R=0.69 ; P=0.031)$, the abundance of alien species $(R=0.82 ; P=0.01)$ and the biomass of alien species $(R=0.61 ; P=0.04)$.

\section{Discussion}

A total of 11 alien macrocrustacean species were found during a recent sampling campaign at the Belgian coastal harbours. Most of these species were discovered during the last two decades (Table 2), which is similar to the general findings in other parts of the North Sea and the Baltic Sea (Gollasch and Nehring 2006). Only a few species were abundantly present in the Belgian coastal harbours and most were only recorded occasionally. During our sampling campaign, the alien species Melita nitida Smith 1873 was recorded only once in Zeebrugge, although according to the literature, this species often co-occurs with the indigenous Melita palmata (Faasse and van Moorsel 2003), which was recorded in more than twenty samples. Faasse and van Moorsel (2003) found that in the Westerscheldt, where the species was recorded for the first time in Belgium, $M$. nitida was restricted to the mesohaline part, where it hided under stones and between oysters. Caprella mutica has also a related indigenous species (Caprella linearis (Linnaeus 1767)) and both species were exclusively found in Zeebrugge. In its area of origin, C. mutica is often found in association with Japanese algae of the genus Sargassum, of which S. muticum (Yendo) Fensholt 1955 is abundantly present along the North Sea coast. This alga produces floating thalli, where $C$. mutica is associated with (Buschbaum and Gutow 2005). In the harbour of Zeebrugge, different algae were found, including S. muticum (Kerckhof et al. 2007), which confirmed the relationship between S. muticum and C. mutica.

With four species, Decapoda represented an important part of the alien macrofauna. The most frequently encountered alien species, Hemigrapsus takanoi, was recorded in more than 20 samples distributed over all harbours. It is likely that former identifications of $H$. penicillatus along the Belgian coast (Dumoulin 2004) are in fact specimens of H. takanoi. Prior to 2005, H. takanoi was not separated from its close relative $H$. penicillatus (De Haan 1835) and therefore the first observations in Europe (Gollasch 1999) mention the occurrence of $H$. penicillatus instead of $H$. takanoi. Based on the combined evidence from electrophoresis, morphology and ecology, Asakura and Watanabe (2005) found that $H$. penicillatus and $H$. takanoi are two different species. Based on their description, we can assume that $H$. takanoi is present along the Belgian coast, because all specimens had only small dots on the ventral side and dots were never observed on the abdominal segments. In addition, expert knowledge and investigation of earlier collected material indicates that $H$. takanoi rather than H. penicillatus has invaded the European coasts (Asakura and Watanabe 2005). H. takanoi, which is present in Belgium since 2003, has rapidly spread and colonised several habitats (Dumoulin 2004). H. takanoi can be found under boulders and rocks or between oysters, mainly in estuaries and harbours (Dumoulin 2004; Asakura and Watanabe 2005; Soors et al. 2010). This species can easily colonise new areas, because the larvae of this crab are pelagic. Moreover, it is found that even adults can be transported via hull fouling of ships (Gollasch 1999). H. takanoi is a possible competitor with other crabs such as the native Carcinus maenas, which has a similar habitat preference (Dumoulin 2004; Soors et al. 2010).

Besides $H$. takanoi, three other alien crab species were found: Hemigrapsus sanguineus (De Haan 1835), Eriocheir sinensis $\mathrm{H}$ Milne Edwards 1853 and Rhitropanopeus harrisii (Gould 1841). H. sanguineus was far less abundant at our sampling sites compared to $H$. takanoi, although 

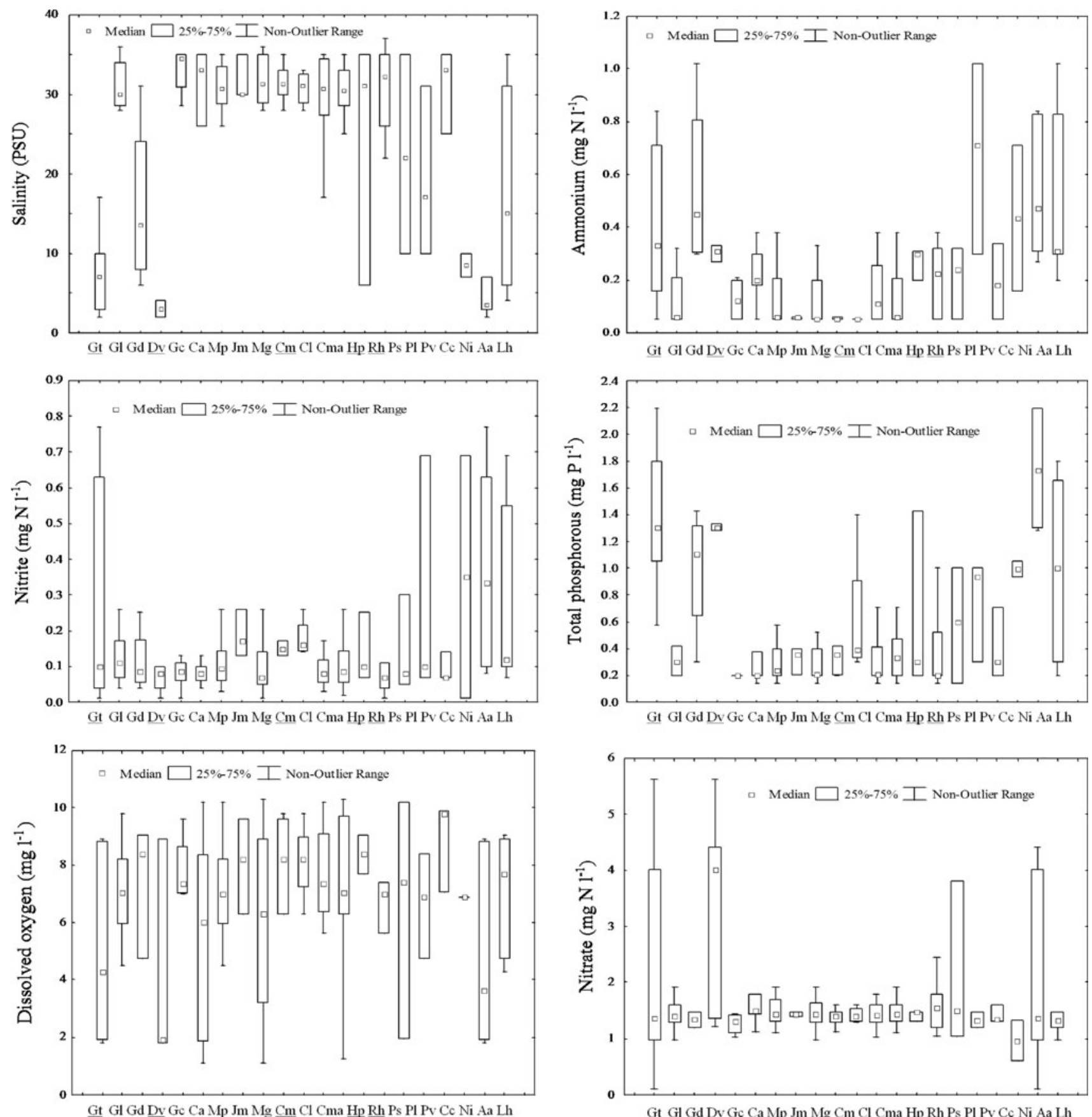

Fig. 3 Box and Whisker plots indicating the range of occurrence of the most common macro-Crustacea (in terms of number of sites where the species was encountered) observed along the Belgian coastal harbours based on the chemical water parameters salinity, ammonium, nitrite, total phosphorous, dissolved oxygen and nitrate. Alien species are underlined (Gt Gammarus tigrinus, Gl Gammarus locusta, Gd Gammarus duebeni, Dv Dikerogammarus villosus,

Kerckhof et al. (2007) stated that this species is abundantly present along the Belgian coast. A possible explanation can be that $H$. sanguineus prefers open rocky shores (Dauvin 2009), which were hardly sampled during our study. Since most of the abovementioned crab species were found

Gc Gammarus crinicornis, Ca Corophium acherusicum, Mp Melita palmata, Jm Jassa marmorata, Mg Microdeutopus gryllotalpa, Cm Caprella mutica, Cl Caprella linearis, Cma Carcinus maenas, $\mathrm{Hp}$ Hemigrapsus penicillatus, Rh Rhitropanopeus harrisii, Ps Palaemon serratus, Pl Palaemon longirostris, Pv Palaemonetes varians, Cc Crangon crangon, Ni Neomysis integer, Aa Asellus aquaticus, Lh Lekanesphaera hookeri)

together, it is likely that competition for food and habitat between the alien species is taking place (Gollasch 1999; Kerckhof et al. 2007; Soors et al. 2010). The only additional alien macrocrustacean species reported earlier from the Belgian coast, but not sampled during recent sampling 


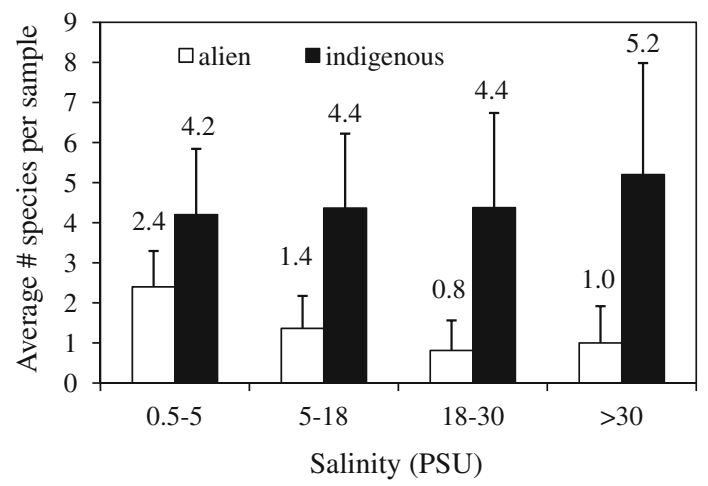

Fig. 4 Average number (with standard deviation) of alien (white) and indigenous (black) species per sample for the different salinity zones (based on the Venice system 1959)

was Callinectes sapidus Rathbun 1896 (Kerckhof and Haelters 2005). The latter alien crab was recorded for the first time in Belgium in 1981 in the Scheldt estuary (Wouters 2002). Currently, C. sapidus is sporadically reported in low numbers from the southern North Sea.

Next to the alien macrocrustaceans mentioned in Table 2, five other alien macrocrustaceans (Synidotea laevidorsalis (Miers 1881), Sinelobus stanfordi Richardson 1901b, Incisocalliope aestuarius (Watling and Maurer 1973), Chelicorophium curvispinum and Hemimysis anomala GO Sars 1907) have been reported from Belgian brackish waters, mainly in the harbour of Antwerp (Verslycke et al. 2000; Ysebaert et al. 2000; Van Haaren and Soors 2009; Messiaen et al. 2010; Soors et al. 2010). Hard substrates, which are often available in harbours, are seen as an important element favouring the success of $S$. laevidorsalis and $S$. stanfordi. Boulders used to be almost absent in estuaries along the southern coasts of the North Sea. Application of artificial hard substrates may have facilitated the introduction of certain alien species (Faasse and van Moorsel 2003). Hard substrates can provide a suitable habitat for several soft bottom species, as these substrates might give shelter and prevent species being washed out from the sediment (Ysebaert et al. 2000). Although Hemimysis anomala was not found during our sampling campaign, the species has been reported at the Galgenweel, a pond situated near the harbour of Antwerp (Verslycke et al. 2000), in the cooling water system of the chemical company BASF situated in het harbour of Antwerp (Pers. Comm. Dr. Nancy Fockedey), in the river Scheldt near the Belgian-Dutch border (Fockedey 2006) and recently in a ditch near the harbour of Ostend (Boets et al. 2011a). All alien species mentioned above thrive very well in a brackish water environment and can therefore also be expected to occur in the near future along the Belgian coast. On top of the already introduced species, more alien species are to be expected from other parts of the world, whereby secondary dispersal via other European harbours can be an important vector.

The highest number of alien species was found in the oligo- and mesohaline zone. This was also observed by Paavola et al. (2005), who found that several brackish water seas (Baltic Sea, Black Sea, Caspian Sea and Sea of Azov) have been invaded frequently resulting in a
Fig. 5 Map with the sitespecific biocontamination index (SBCI) (Arbačiauskas et al. 2008) for the sampling sites situated in a Nieuwpoort, b Ostend and c ZeebruggeBlankenberge. SBCI classes: $O$ (no biocontamination), 1 (low biocontamination), 2 (moderate biocontamination), 3 (high biocontamination) and 4 (severe biocontamination)
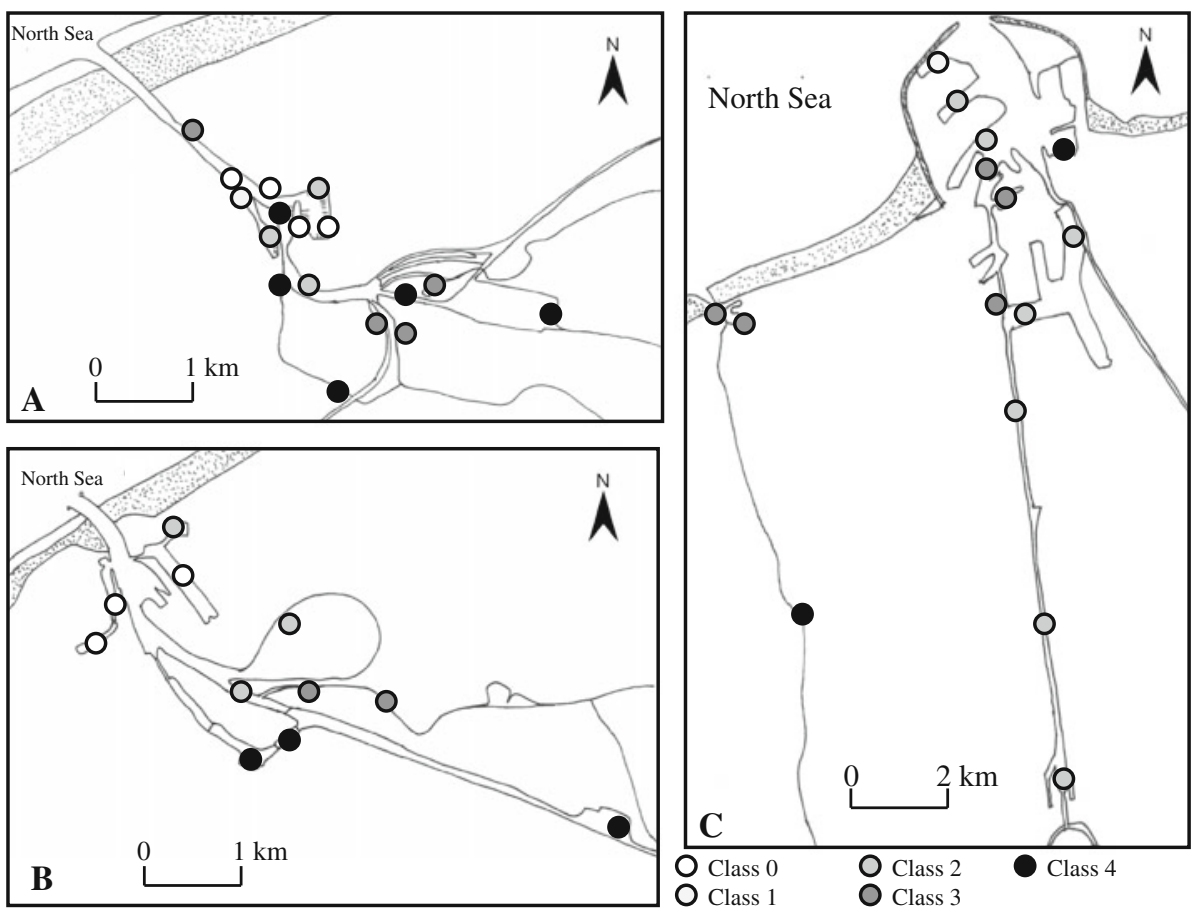
maximum number of alien species present in the oligohaline zone. The natural species minimum in brackish water as reported by several authors (Remane 1958; Wolff 1999; Paavola et al. 2005; Nehring 2006) was confirmed during our study. Consequently, the hypothesis stating that the low indigenous species richness in brackish water leaves many empty niches favouring the establishment of alien species could be confirmed. Most sampling locations in the oligohaline zone were situated in canals and rivers with a low water quality, which could contribute to the low native species diversity. Alien species are often more tolerant to a low water quality and hence more successful in these degraded habitats (Kennard et al. 2005; Boets et al. 2011b). Salinity is often considered to be a good parameter for risk assessment of future invasions of brackish water areas (Paavola et al. 2005). Areas with similar salinities can act as a potential donor region since genuine brackish water species can easily adapt to new habitat conditions. The fact that brackish waters have a higher potential for invasions due to intensive international ship traffic in combination with the physiological adaptations of brackish water species, enabling them to survive the transportation via ballast water, could explain the high number of alien species encountered in the mesohaline zone (Paavola et al. 2005). In addition, brackish waters are subjected to a two-sided invasion pressure by alien species, via the ocean and via inland waters, which could contribute to the high number of alien species encountered (Nehring 2006). The presence of empty niches, suitable environmental conditions and availability of proper vectors might be the most effective predictors to determine the susceptibility to invasions of brackish waters (Paavola et al. 2005).

When investigating the number of alien species, Zeebrugge was the harbour with the highest number of alien macro-crustaceans, which is reflected by a high site-specific biocontamination index. The harbour of Zeebrugge received the highest number of transcontinental commercial ships compared to the other harbours. It is known that many alien species are being transported via ballast water of ships (Ruiz et al. 1997). A positive correlation between shipping and the number of alien species established confirmed that shipping is probably the most important vector of species introductions. The so-called propagule pressure, which is related to the introduction of alien species, is seen as an important element in the establishment success of alien species, although it is not always taken into account in studies about biological invasions (Williamson and Fitter 1996). Propagule pressure is not always easy to measure, but can be related to the intensity of unintentional introductions, such as the estimated quantities of discharged ballast water, or the number of ships that might carry fouling on hulls (Occhipinti-Ambrogi 2007). Whereas the number of alien species is related to propagule pressure, the high abundance of certain alien species can be ascribed to favourable environmental conditions (e.g. habitat suitability) (Crooks and Soulé 1999). Despite the fact that most observed alien species originated from North America, most ships which anchor in Zeebrugge originated from European harbours and only a small part originated from North America. Frequent commercial shipping between neighbouring countries in Europe or countries bordering the same sea might be responsible for secondary introductions and dispersal of alien species. Moreover, also secondary dispersal via yachts or fishing vessels originating from neighbouring harbours could have partially contributed to introduction and spread of these alien species. Besides North America, also East Asia was an important donor region. According to Gollasch and Nehring (2006) and Kerckhof et al. (2007), three prime source regions of aquatic alien species could be distinguished for the North Sea: Northwest Atlantic, Indo-Pacific and North Pacific.

Although there are no clear examples of species extinctions in the North Sea due to the introduction of alien species, the distribution area of indigenous species may have been reduced (Reise et al. 1999). Moreover, there exists the danger that the introduction of alien species can cause the spread of associated organisms or diseases, which may affect native species and cause economical damage (Ruiz et al. 1997). In addition, there is the ongoing threat of global warming, which may be beneficial for certain alien species to spread and establish. Since the underlying mechanisms of species introductions are still not fully understood and their impact is very unpredictable, we should be aware of new species introductions (Gollasch and Nehring 2006). Therefore, an active management with control of ballast water and an effective legislation regarding the introduction of species is an essential element to prevent more introductions of alien species.

Acknowledgments We would like to thank the Flanders Marine Institute (VLIZ) for the information they provided regarding useful literature and shipping data and for the use of their infrastructure. A special thanks goes to André Catrijsse and Michiel T'Jampens of the VLIZ for their support during the sampling campaign. We would like to thank Lot Hebbelinck for her support during sampling and identification. We are also grateful to the different marinas and harbours who gave their authorization to place substrates and provided us with useful information on the number of recreational crafts visiting the marinas. Our thanks to two anonymous reviewers who helped us improving this manuscript and made us aware of the difference between Hemigrapsus takanoi and $H$. penicillatus. Koen Lock is currently supported by a post-doctoral fellowship from the Fund for Scientific Research (FWO-Vlaanderen, Belgium).

\section{References}

Arbačiauskas K, Semenchenko V, Grabowski M, Leuven RSEW, Paunovic M, Csanyi B, Gumuliauskaite S, Konopacka A, Nehring S, Van der Velde G, Vezhnovetz V, Panov VE (2008) 
Assessment of biocontamination of benthic macroinvertebrate communities in European inland waterways. Aquat Invasions 3:211-230

Asakura A, Watanabe S (2005) Hemigrapsus takanoi, new species, a sibling species of the common Japanese intertidal crab H. penicillatus (Decapoda: Brachyura: Grapsoidea). J Crust Biol 25:279-292

Bernauer D, Jansen W (2006) Recent invasions of alien macroinvertebrates and loss of native species in the upper Rhine River, Germany. Aquat Invasions 1:55-71

Bij de Vaate A, Jazdzewski K, Ketelaars HAM, Gollasch S, van der Velde G (2002) Geographical patterns in range extension of Ponto-Caspian macroinvertebrate species in Europe. Can J Fish Aquat Sci 59:1159-1174

Boets P, Lock K, Goethals PLM (2011a) Shifts in the Gammarid (Amphipoda) fauna of brackish polder waters in Flanders (Belgium). J Crust Biol 31:270-277

Boets P, Lock K, Goethals PLM (2011b) Using long-term monitoring to investigate the changes in species composition in the harbour of Ghent (Belgium). Hydrobiologia 663:155-166

Buschbaum C, Gutow L (2005) Mass occurrence of an introduced crustacean (Caprella cf. mutica) in the south-eastern North Sea. Helgol Mar Res 59:252-253

Cardoso AC, Free G (2008) Incorporating invasive alien species into ecological assessment in the context of the water framework directive. Aquat Invasions 3:361-366

Conover WJ (1980) Practical non-parametric statistics. Wiley, New York

Cook EJ, Jahnke M, Kerckhof F, Minchin D, Faasse M, Boos K, Ashton G (2007) European expansion of the introduced amphipod Caprella mutica Schurin 1935. Aquat Invasions 2:411-421

Crooks KR, Soulé ME (1999) Mesopredator release and avifaunal extinctions in a fragmented system. Nature 400:563-566

Dauvin JC (2009) Establishment of the invasive Asian shore crab Hemigrapsus sanguineus (De Haan, 1853) (Crustacea: Brachyura: Grapsoidea) from the Cotentin Peninsular, Normandy, France. Aquat Invasions 4:467-472

d'Udekem d'Acoz C (2006) First record of the Asian shore crab Hemigrapsus sanguineus (DeHaan, 1835) in Belgium (Crustacea, Brachyura, Grapsoidea). De Strandvlo 26:74-82

Dumoulin E (2004) Quick range extension of pencil-crab Hemigrapsus penicillatus (de Haan, 1835) along the coasts of the Southern Bight of the North Sea, status of its intrusion in the Westerschelde, and considerations on its ecology and behaviour. De Strandvlo 24:5-35

Eno NC, Clark RA, Sanderson WG (1997) Non-native species in British waters: a review and directory. Joint Nature Conservation Committee, Peterborough $152 \mathrm{p}$

European Community (2000) Directive 2000/60/EC of the European parliament and of the council of 23 October 2000 establishing a framework for community action in the field of water policy. Off J Eur Communities L327: 1-72

Faasse M, Van Moorsel G (2003) The North-American amphipods, Melita nitida Smith, 1873 and Incisocalliope aestuarius (Watling and Maurer, 1973) (Crustacea: Amphipoda: Gammaridea), introduced to the western Scheldt estuary (The Netherlands). Aquat Ecol 37:13-22

Fockedey N (2006) Mysid shrimp populations in the Scheldt estuary. ENDIS-RISKS project data (2002-2006) in IMERS (http:// www.vliz.be/vmdcdata/imers). Endocrine disruption in the Scheldt estuary: distribution, exposure and effects. SPSD IIBelgian Science Policy. UGent-Marine Biology Section

Gabriels W, Lock K, De Pauw N, Goethals PLM (2010) Multimetric Macroinvertebrate index flanders (MMIF) for biological assessment of rivers and lakes in Flanders (Belgium). Limnologica 40:199-207
Gollasch S (1999) The Asian decapod Hemigrapsus penicillatus (de Haan, 1835) (Grapsidae, Decapoda) introduced in European waters: status quo and future perspective. Helgol Mar Res $52: 359-366$

Gollasch S (2006) Overview on introduced aquatic species in European navigational and adjacent waters. Helgol Mar Res 60:84-89

Gollasch S, Nehring S (2006) National checklist for aquatic alien species in Germany. Aquat Invasions 1:245-269

Grabowski M, Bacela K, Konopacka A (2007) How to be an invasive gammarid (Amphipoda: Gammaroidea)-comparison of life history traits. Hydrobiologia 590:75-84

Kennard MJ, Arthington AH, Pussey BJ, Harch BD (2005) Are alien fish a reliable indicator of river health? Freshwater Biol 50:174-193

Kerckhof F, Haelters J (2005) Enkele opmerkelijke waarnemingen en strandingen in 2004 en 2005. De Strandvlo 25:101-105

Kerckhof F, Haelters J, Gollasch S (2007) Alien species in the marine and brackish ecosystem: the situation in Belgian waters. Aquat Invasions 2:243-257

Massin Cl, Norro A, Mallefet J (2002) Biodiversity of a wreck from the Belgian continental shelf: monitoring using scientific diving: preliminary results. R B I N S 72:67-72

Mathys C (2009) Economic importance of the Belgian ports: Flemish maritime ports, Liège port complex and the port of BrusselsReport 2007. Working paper document, 72, $108 \mathrm{p}$

Mees J (1994) The hyperbenthos of shallow coastal waters and estuaries: community structure and biology of the dominant species. PhD Thesis, University of Gent, $212 \mathrm{p}$

Merckx JP, Neyts D (2008) Jaaroverzicht Vlaamse havens 2008: Feiten en ontwikkelingen, investeringen, sociaaleconomische indicatoren en statistieken over 2008. 138 p (in Dutch)

Messiaen M, Lock K, Gabriels W, Vercauteren T, Wouters K, Boets P, Goethals PLM (2010) Alien macrocrustaceans in freshwater ecosystems in the eastern part of Flanders (Belgium). Belg $\mathrm{J}$ Zool 140:30-39

Nehring S (2006) Four arguments why so many alien species settle into estuaries, with special reference to the German River Elbe. Helgol Mar Res 60:127-134

Noordhuis R, van Schie J, Jaarsma N (2009) Colonization patterns and impacts of the invasive amphipods Chelicorophium curvispinum and Dikerogammarus villosus in the IJsselmeer area, The Netherlands. Biol Invasions 11:2067-2084

Nuyttens F, Versele G, Loones M-A (2006) De aanwezigheid van de penseelkrab Hemigrapsus takanoi en de blaasjeskrab Hemigrapsus sanguineus in Nieuwpoort- Bad. De Strandvlo 26:113-115

Occhipinti-Ambrogi A (2007) Global change and marine communities: alien species and climate change. Mar Pollut Bull 55:342-352

Paavola M, Olenin S, Leppäkoski E (2005) Are invasive species most successful in habitats of low native species richness across European brackish water seas? Estuar Coast Shelf S $64: 738-750$

Panov VE, Alexandrov B, Arbačiauskas K, Binimelis R, Copp GH, Grabowski M, Lucy F, Leuven RSEW, Nehring S, Paunović M, Semenchenko V, Son MO (2009) Assessing the risks of aquatic species invasions via European inland waterways: from concepts to environmental indicators. Integr Environ Assess Manage $5: 110-126$

Reise K, Gollasch S, Wolff WJ (1999) Introduced marine species of the North Sea coasts. Helgol Meeresunt 52:219-234

Remane A (1958) Oekologie des Brackwassers. Die Binnengewaesser, Stuttgart, $22 \mathrm{p}$

Ruiz GM, Hewitt CL (2002) Toward understanding patterns of coastal marine invasions: a prospectus. Invasive aquatic species of Europe: distribution, impacts and management, pp 529-583 
Ruiz GM, Carlton JT, Grosholz ED, Hines AH (1997) Global invasions of marine and estuarine habitats by non-indigenous species: mechanisms, extent, and consequences. Am Zool 37:621-632

Seys J, Vincx M, Meire P (1999) Spatial distribution of oligochaetes (Clitellata) in the tidal freshwater and brackish parts of the Schelde estuary (Belgium). Hydrobiologia 406:119-132

Soors J, Faasse M, Stevens M, Verbessem I, De Regge N, Van den Bergh E (2010) New crustacean invaders in the Schelde estuary (Belgium). Belg J Zool 140:3-10

Stachowicz JJ, Whitlatch RB, Osman RW (1999) Species diversity and invasion resistance in a marine ecosystem. Science 286:1577-1579

StatSoft, Inc (2004) STATISTICA (data analysis software system), version 7. http://www.statsoft.com

Streftaris N, Zenetos A, Papathanassiou E (2005) Globalisation in marine ecosystems: the story of non-indigenous marine species across European seas. Oceanogr Mar Biol Ann Rev 43:419-453

Van der Velde G, Rajagopal S, Kelleher B, Muskó IB, Bij de Vaate A (2000) Ecological impact of crustacean invaders: general considerations and examples from the Rhine River. Crustacean Iss $12: 3-33$

Van Haaren T, Soors J (2009) Sinelobus stanfordi (Richardson, 1901): a new crustacean invader in Europe. Aquat Invasions 4:703-711
Venice system (1959) The final resolution of the symposium on the classification of brackish waters. Arch Oceanogr Limnol 11 (suppl):243-248

Verslycke T, Janssen C, Lock K, Mees J (2000) First occurrence of the Pontocaspian invader Hemimysis anomala (Sars, 1907) in Belgium (Crustacea : Mysidacea). Belg J Zool 30:157-158

VLIZ (2007) Checklist for aquatic alien species in the Belgian part of the North Sea and adjacent estuaries. Flanders Marine Institute (VLIZ), Belgium. Searched on 2011-02-16

Williamson MH, Fitter A (1996) The characters of successful invaders. Biol Conserv 78:163-170

Wolff WJ (1999) Exotic invaders of the meso-oligohaline zone of estuaries in the Netherlands: why are there so many? Helgol Meeresunt 52:393-400

Wouters K (2002) On the distribution of alien non-marine and estuarine macro-crustaceans in Belgium. R B I N S 72:119-129

Ysebaert T, Meire P, Maes D, Buijs J (1993) The benthic macrofauna along the estuarine gradient of the Schelde estuary. Neth J Aquat Ecol 27:327-341

Ysebaert T, De Neve L, Meire P (2000) The subtidal macrobenthos in the mesohaline part of the Schelde Estuary (Belgium): influenced by man? J Mar Biol Assoc UK 80:587-597 